\title{
イチゴの四季成り性品種間における花芽分化の限界日長の差異
}

\author{
西山 学 $*$ ・海老原康仁 ${ }^{\mathrm{a}} \cdot$ 金浜耕基 \\ 東北大学大学院農学研究科９81-8555 仙台市青葉区堤通雨宮町
}

\section{Differences in Critical Photoperiod for Flower Bud Initiation among Everbearing Strawberry Cultivars}

\author{
Manabu Nishiyama*, Yasuhito Ebihara ${ }^{\mathrm{a}}$ and Koki Kanahama \\ Graduate School of Agriculture, Tohoku University, Sendai, Miyagi 981-8555
}

\begin{abstract}
Four everbearing strawberry (Fragaria $\times$ ananassa Duch.) cultivars, 'Kaho', 'Ohishi-shikinari', 'Miyoshi' and 'Yamatoshikinari', which were overwintered, were grown at day (6:00-18:00)/night (18:00-6:00) temperatures of 30/25 ${ }^{\circ} \mathrm{C}$ under 12 -, 13-, 14- and 15-h photoperiods for 16 weeks. 'Yamato-shikinari' was also grown under a 16-h photoperiod. Under such a high temperature condition, these cultivars were found to be qualitative long-day plants. Flower bud initiation was inhibited under 14-h or shorter photoperiod in 'Kaho', under 13-h or shorter in 'Ohishi-shikinari', under 12-h in 'Miyoshi' and 15-h or shorter in 'Yamato-Shikinari'. Non-chilled 'Kaho' and 'Ohishi-shikinari' plants were also tested. The photoperiods under which their flower bud initiation was inhibited were the same as those of overwintered plants. The critical photoperiod for flower bud initiation in everbearing strawberry plants grown under high temperature varied among cultivars.
\end{abstract}

Key Words : high temperature, reproductive growth, vegetative growth

キーワード：栄養成長，高温，生殖成長

\section{緒言}

現在，日本で栽培されているイチゴ（Fragaria $\times$ ananassa Duch.）の主要な品種である一季成り性品種は短日性であ る. 一方, 夏季の栽培に利用されている四季成り性品種は, $26^{\circ} \mathrm{C}$ より低い温度に执いては日長が長いほど花房を多く 発生させる量的長日性であると報告されている (Durner ら, 1984; 施山ら, 1989; Smeets, 1980; 泰松, 1993). 既報（西山 ら，1998, 1999）に扎いて，“サマーベリー’を6〜18 時の 昼温 $/ 18$ 時〜翌日の 6 時の夜温を $20 / 15^{\circ} \mathrm{C}$ あるいは $25 / 20^{\circ} \mathrm{C}$ とし，日長を 8 時間あるいは 24 時間として栽培した場合， 開花花房はいずれの日長でも連続的に発生したが，24 時間 日長で多く，量的長日性であることが示された。しかし， $30 / 25^{\circ} \mathrm{C}$ で栽培した場合, 8 時間日長では花芽の分化が停止 する一方で, 24 時間日長では花芽の分化, 発達が促進され る質的長日性であることが示された，花芽分化に必要な最 長または最短の日長を限界日長と呼ぶ. そこで, ‘サマーベ リー、に颃いても花芽の分化が停止する日長と促進される 日長の境となる日長を「限界日長」と呼ぶこととした。“サ

2007 年 7 月 4 日 受付. 2008 年 6 月 30 日 受理.

本報告の一部は園芸学会平成 12 年度春季大会で発表した.

* Corresponding author. E-mail: nissy@bios.tohoku.ac.jp

a 現在 : 農林水産省

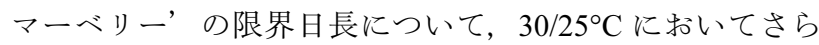
に細かく調べたところ，13 時間と 14 時間の間に存在する とみられた（Nishiyama ら，2006）。

四季成り性品種の栽培に扣いて，高い温度で花芽分化が 抑制されることが報告されている（川下, 1988; Oda・Yanagi, 1990; 施山・今田, 1990; 泰松, 1993; 泰松・芳岡, 1984）. 一方，夏季に電照を行うことにより花芽分化や開花が促進 されることが報告されている（川村ら，1990; 川下，1988; 高野・常松, 1993, 1994; 施山・今田, 1990; 泰松, 1993; 刀 袮, 1992）.これらの現象について, これまで調べた“サ マーベリー’の結果から類推すると，夏季に花芽分化が抑 制される原因は，高温と限界日長より短い日長が組み合わ さることが考えられ，夏季に花芽分化させるには，限界日 長以上の日長で栽培する必要があると考えられる.

このよらに, ‘サマーベリ一’ で明らかにされた四季成り 性品種の限界日長は，四季成り性品種の夏季の高温期の栽 培に扣いて重要な形質であるとみられたので，本報では， ‘サマーベリー’ とは異なる四季成り性品種を $30 / 25^{\circ} \mathrm{C}$ で栽 培して限界日長が認められるか調べることとした。

\section{材料および方法}

\section{1. 供試品種}

材料には, ‘サマーベリー’の種子親である四季成り性品 種の“夏芳’，日本で育成された古典的な四季成り性品種 
Table 1 Outlines of the cultivations.

\begin{tabular}{lcccc}
\hline \hline Cultivars & Runner plant development $^{\mathrm{z}}$ & Potting $^{\mathrm{y}}$ & Transferred $^{\mathrm{x}}$ & Treatment started $^{\mathrm{w}}$ \\
\hline Kaho and Ohishi-shikinari (non-chilled) & Summer in '97 & 5 Oct. '97 & 8 Nov. '97 & 18 Nov. '97 \\
Kaho and Ohishi-shikinari & Summer in '96 & 20 Apr. '97 & 25 May '97 & 4 Jun. '97 \\
Miyoshi & Summer in '98 & 1 Apr. '99 & 5 May '99 & 12 May '99 \\
Yamato-shikinari & Summer in '02 & 28-29 Oct. '02 & 20 May '03 & 27 May '03 \\
\hline
\end{tabular}

${ }^{\mathrm{z}}$ Plants were grown in a nursery field until potting.

${ }^{y}$ After potting, plants were grown in the nursery field (non-chilled 'Kaho' and 'Ohishi-shikinari') or an unheated glasshouse (other cultivars).

${ }^{x}$ Plants were transferred into the phytotrons controlled at a day (6:00-18:00)/night (18:00-6:00) temperature of $25 / 20^{\circ} \mathrm{C}$ under natural daylength for acclimatization until high temperature and photoperiod treatment started.

${ }^{w}$ From this date, high temperature and photoperiod treatment started. Plants were grown in the phytotrons controlled at $30 / 25^{\circ} \mathrm{C}$ under various photoperiods for 16 weeks. For photoperiods, see Table 2.

で，その後の四季成り性品種の交配親として用いられてき た ‘大石四季成”（種苗名称登録される前の名前は，“大石 四季成二号' (高橋, 2000)), 徳島県で育成され, 栽培実績 のあった '久ょし’，来歴や研究例が不明であるが，将来的 に育種素材として用いることを考慮して, 農林水産省野菜・ 茶業試験場盛岡支場（当時）から入手した ‘大和四季成” を供試した．低温前歴の影響を調べることを目的として， “夏芳” ‘大石四季成” は, 第 1 表に示寸ように, 低温に ほとんど遭遇させていない株と十分に遭遇させた株を供試 した。 それぞれの $5^{\circ} \mathrm{C}$ 以下の低温遭遇時間は，35 時間と 2,071 時間であった.

\section{2. 栽培と日長処理の方法}

各品種の栽培概要を第 1 表に示した。栽培は, 品種や低 温遭遇の有無に関わらず，同様に行った，すなわち，直径 $18 \mathrm{~cm}$ の素焼きの鉢に株を鉢上げした。用土として園芸用 土: 堆肥: バーミキュライトを $5: 3: 2$ の割合で混合したも のを用いた，基肥として CDU 化成肥料（N: $\mathrm{P}_{2} \mathrm{O}_{5}: \mathrm{K}_{2} \mathrm{O}=$ $15: 15: 15)$ を 1 鉢当たり $3 \mathrm{~g}$ ずつ $\left(\mathrm{N}, \mathrm{P}_{2} \mathrm{O}_{5}, \mathrm{~K}_{2} \mathrm{O}\right.$ は各 $0.45 \mathrm{~g} /$ 鉢）施与した. 高温・日長処理の開始後は, 追肥として $\mathrm{CDU}$ 化成肥料を 2 週間に $1 \mathrm{~g}$ ずつ $\left(\mathrm{N}, \mathrm{P}_{2} \mathrm{O}_{5}, \mathrm{~K}_{2} \mathrm{O}\right.$ は各 $0.15 \mathrm{~g} /$ 鉢）施肥した。灌水は 1 日 1 回行った.

鉢上げ後は, 低温飞遭遇させていない“夏芳”と ‘大石 四季成’ は露地で，その他の品種は自然日長下の無加温の ガラス室で栽培した。 その後, $6 \sim 18$ 時の昼温 $/ 18$ 時〜翌 日の 6 時の夜温を $25 / 20^{\circ} \mathrm{C}$ に設定した自然日長下のファイ トトロン内に搬入して 7〜10 日間順化させてから, 昼温/ 夜温を $30 / 25^{\circ} \mathrm{C}$ に設定するとともに，日長処理を開始した。

自然光型ファイトトロン内に 12 時間，13 時間，14 時間， 15 時間の日長処理区を設けた。“大和四季成”は 16 時間日 長区も設けた，全ての日長処理区に扔いて，9〜17 時まで 自然光下で栽培し, 17 時から翌日の 9 時までは厚さ $0.07 \mathrm{~mm}$ のシルバーポリフィルムを二重にした覆いで遮光した，遮 光した処理区の中で， 12 時間日長区は $17 〜 21$ 時まで，13 時間日長区は $17 \sim 22$ 時まで, 14 時間日長区は $17 \sim 23$ 時 まで，15 時間日長区は $17 〜 24$ 時まで，16 時間日長区は 17 時〜翌日の 1 時まで電照した. 光源には $100 \mathrm{~W}$ の白熱電
球を用いて補光した．株の直上の光量子束密度は 26.0 〜 $36.5 \mu \mathrm{mol} \cdot \mathrm{m}^{-2} \cdot \mathrm{s}^{-1}$ であった．高温・日長処理は 16 週間 行った.

\section{3. 調查方法}

高温・日長処理を開始する時に，肉眼で見える程度に発 達していた花芽とランナーをすべて摘除した．この時，分 枝していた分げつを 2 本残して他の分げつは摘除した，処 理期間中は，旺盛な分げつを 1 本選び，これを一つの株と 見なして調査を行った，イチゴでは，主枝の腋芽から発達 した側枝を 1 次側枝, 1 次側枝の腋芽から発達した側枝を 2 次側枝のよらに呼ぶ．本実験で一つの株と見なした分げ つは，本来は側枝であるが，便宜的に主枝とみなした，も う1本の分げつについては調査しなかった。なお，高温・ 日長処理開始時に摘除した分げつを分解して茎頂を実体顕 微鏡で観察したところ, 品種や低温遭遇の有無に関わらず, 全ての分げっで花芽が分化していた.

高温・日長処理の開始後, 新しく展開した葉の数（展開 葉数), 一つ以上の花が開花した花房の数（開花花房数）, 発生したランナーと側枝の数を 1 週間ごとに調査した. な お，本報ではランナーと側枝の数のデータは割愛した。調 查した開花花房数は 4 週間ごとに合計して 1 株当たりの平 均値を求め, 第 1 図に表した. 調査した開花花房とランナー は摘除した. イチゴの栽培では，側枝を $1 \sim 2$ 本残して摘 除することがあるが，本実験では摘除しなかった。

各日長処理区に，低温に遭遇していない“夏芳”と ‘大 石四季成” 9 株，低温に遭遇した “夏芳” ‘ ‘石四季 成’は 5 株，“久よし’は9 株，“大和四季成’は 10 株供試 したが，処理期間中に枯死した株はデータから除外した. 供試した株数は第 2 表に示した.

\section{結果}

処理期間中に展開した葉数の日長処理区による差は, “大 和四季成”で認められた (第 2 表)。他の品種では有意な差 は認められなかったものの，低温に遭遇していない’大石 四季成” の 13 時間日長区と 15 時間日長区のように，平均 值を見ると差があると見られる処理区もあった（第 2 表）。 
Table 2 Effect of photoperiod on the growth of everbearing strawberry cultivars grown at high temperature ${ }^{\mathrm{z}}$.

\begin{tabular}{|c|c|c|c|}
\hline \multirow{2}{*}{ Photoperiod (h) } & \multirow{2}{*}{$\begin{array}{c}\text { Number of } \\
\text { plants observed }\end{array}$} & \multicolumn{2}{|c|}{ Number per plant } \\
\hline & & Expanded leaves & Inflorescences \\
\hline \multicolumn{4}{|c|}{ Kaho (non-chilled) } \\
\hline 12 & 9 & $17.3 \mathrm{a}^{\mathrm{y}}$ & $3.2 \mathrm{~b}$ \\
\hline 13 & 7 & $19.6 \mathrm{a}$ & $3.3 \mathrm{~b}$ \\
\hline 14 & 9 & $19.9 \mathrm{a}$ & $3.9 \mathrm{ab}$ \\
\hline 15 & 9 & $21.0 \mathrm{a}$ & $6.3 \mathrm{a}$ \\
\hline \multicolumn{4}{|c|}{ Ohishi-shikinari (non-chilled) } \\
\hline 12 & 6 & $26.2 \mathrm{a}$ & $1.7 \mathrm{~b}$ \\
\hline 13 & 5 & $23.6 \mathrm{a}$ & $2.2 \mathrm{~b}$ \\
\hline 14 & 8 & $32.1 \mathrm{a}$ & $7.8 \mathrm{a}$ \\
\hline 15 & 7 & $34.3 \mathrm{a}$ & $9.3 \mathrm{a}$ \\
\hline \multicolumn{4}{|l|}{ Kaho } \\
\hline 12 & 5 & $16.6 \mathrm{a}$ & $4.6 \mathrm{~b}$ \\
\hline 13 & 5 & $16.6 \mathrm{a}$ & $6.2 \mathrm{~b}$ \\
\hline 14 & 4 & $15.3 \mathrm{a}$ & $5.8 \mathrm{~b}$ \\
\hline 15 & 4 & $20.0 \mathrm{a}$ & $11.8 \mathrm{a}$ \\
\hline \multicolumn{4}{|c|}{ Ohishi-shikinari } \\
\hline 12 & 5 & $21.6 \mathrm{a}$ & $5.8 \mathrm{a}$ \\
\hline 13 & 4 & $14.3 \mathrm{a}$ & $6.5 \mathrm{a}$ \\
\hline 14 & 5 & $21.6 \mathrm{a}$ & $12.0 \mathrm{a}$ \\
\hline 15 & 5 & $21.0 \mathrm{a}$ & $11.4 \mathrm{a}$ \\
\hline \multicolumn{4}{|l|}{ Miyoshi } \\
\hline 12 & 7 & $18.0 \mathrm{a}$ & $5.3 \mathrm{~b}$ \\
\hline 13 & 8 & $13.1 \mathrm{a}$ & $7.4 \mathrm{ab}$ \\
\hline 14 & 6 & $14.2 \mathrm{a}$ & $8.2 \mathrm{ab}$ \\
\hline 15 & 7 & $13.6 \mathrm{a}$ & $8.4 \mathrm{a}$ \\
\hline \multicolumn{4}{|c|}{ Yamato-shikinari } \\
\hline 12 & 10 & $24.2 \mathrm{ab}$ & $2.7 \mathrm{~b}$ \\
\hline 13 & 9 & $19.0 \mathrm{~b}$ & $2.3 \mathrm{~b}$ \\
\hline 14 & 9 & $19.4 \mathrm{~b}$ & $2.3 \mathrm{~b}$ \\
\hline 15 & 10 & $19.4 \mathrm{~b}$ & $3.7 \mathrm{~b}$ \\
\hline 16 & 10 & $27.4 \mathrm{a}$ & $8.3 \mathrm{a}$ \\
\hline
\end{tabular}

${ }^{\mathrm{z}}$ Plants were grown at day (6:00-18:00)/night (18:00-6:00) temperatures of $30 / 25^{\circ} \mathrm{C}$ for 16 weeks. The outlines of cultivation for each cultivar are shown in Table 1.

${ }^{\mathrm{y}}$ Different letters within cultivars and columns indicate significance at $\mathrm{P}=0.05$ by Tukey-Kramer multiple comparisons test.

処理期間中に開花した花房数は, 低温に遭遇した“大石四 季成’では日長処理区間で有意な差は認められなかったも のの，14，15 時間日長区で多いものとみられた。低温に遭 遇していない“大石四季成” では 14，15 時間日長区で有意 に多かった。 ‘夏芳”では低温遭遇の有無に関わらず 15 時 間日長区で多かった。 ‘久よし’では 13，14，15 時間日長 区で多く，“大和四季成”では 16 時間日長区で有意に多かっ た（第 2 表).

開花花房の発生は, 日長処理区により, 処理終了時までに 停止するものと発生し続けるものが認められた (第 1 図). その境となる日長には, 品種による違いがみられた。 “夏芳” の場合は，低温遭遇の有無に関わらず，14 時間日長区と 15 時間日長区の間, “大石四季成” の場合は, 低温遭遇の有無 に関わらず, 13 時間日長区と 14 時間日長区の間, ‘久よし’
の場合は，12 時間日長区と 13 時間日長区の間，“大和四季 成”の場合は, 15 時間日長区と 16 時間日長区の間であった.

それぞれの品種において，開花花房の発生が停止した側 枝の茥頂を実体顕微鏡で観察したところ，花芽は認められ なかった。

以上の結果, $30 / 25^{\circ} \mathrm{C}$ に打ける花芽分化の限界日長は, “夏芳’ は 14 時間と 15 時間の間，“大石四季成’は 13 時間 と 14 時間の間，“みょし’は 12 時間と 13 時間の間，“大和 四季成”は15時間と16時間の間に存在することが示された.

\section{考察}

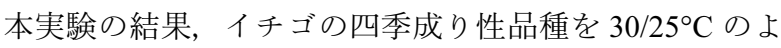
らな高温条件下で生育させると, ‘サマーベリ一’以外の品 種も花芽分化の限界日長が示され，限界日長より短い日長 では花芽分化が停止する質的長日性を示すことと，限界日 長は 12 時間から 16 時間の間で品種間差があることが示さ れた，質的長日性が示されるのは，高温と短日の組み合わ さった条件下であると見られるが，“夏芳”では平均気温 $26^{\circ} \mathrm{C}$ 付近で 15 時間より短い自然日長条件下 (泰松・芳岡, 1984), “大石四季成’ では $30 / 25^{\circ} \mathrm{C}$ の 12 時間日長（施山ら, 1989）で花芽分化や花房の発生が抑制されると報告されて おり，本実験の結果と一致した。

熊倉・宍戸（1995）は，四季成り性品種の“エバーべ リー’，‘円雷’，‘サマーベリ一’を供試して，30ㄷ に拈い て，4 時間， 8 時間， 16 時間日長で栽培した場合，発育が 途中で停止するものの，花芽が分化することを指摘してい る.しかし，本実験では，いずれの品種も，限界日長より 短い日長では花芽の分化が認められず，限界日長より長い 日長では花芽は正常に発達した，熊倉・宍戸（1995）にお いて，16 時間日長で花芽が座止した原因は，温度が $30^{\circ} \mathrm{C}$

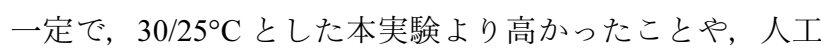
光で栽培したために，自然光で栽培した本実験より光強度 が弱く, 光合成産物が十分に生産されなかったことが考兄 られる. 一方, 本実験より高温・短日の条件下に拈いても, 熊倉・宍戸（1995）で花芽が分化した原因は不明である.

“夏芳” ‘大石四季成” は，ランナーが発生した年の 11 月と, 露地で越冬させた翌年の 6 月に同様の高温・日長処 理を開始したが，いずれの品種も，低温遭遇の有無に関わ らず，限界日長が認められた。 ‘サマーベリー’でも，6月 に発生したランナー苗を7月から処理した場合（西山ら, 1999), 7 ～月 に発生したランナー苗を 12 月から処理した 場合（西山ら，1998）, 露地で越冬させた苗を供試した場合 (Nishiyama・Kanahama, 2002）で限界日長が示されたことか ら，株の低温前歴に関わらず，イチゴの四季成り性品種を $30 / 25^{\circ} \mathrm{C}$ で栽培すると, 質的長日性を示すと考えられる.

なお，温度について，四季成り性品種と同様に長日で花 芽分化する品種群である Day-neutral 型品種の 'Tribute’ を 栽培した場合，通常，夏でも花芽分化するところ，気温が $35^{\circ} \mathrm{C}$ 以上の年は花芽分化が抑制されたことが報告されて 


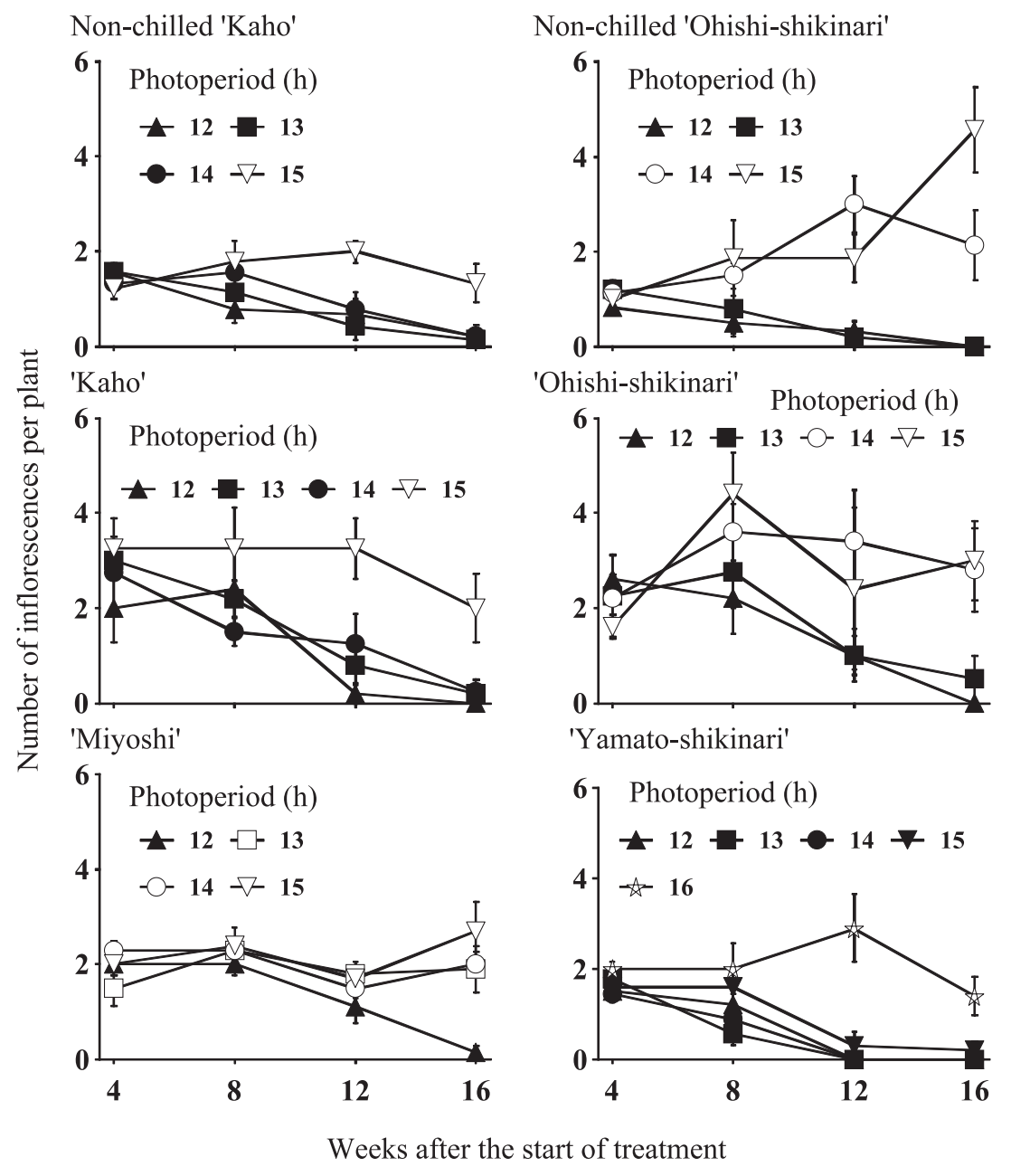

Fig. 1 Effect of photoperiod on the number of inflorescences per plant grown at $30 / 25^{\circ} \mathrm{C}$. Data are shown as averages of every 4 -week period. Vertical bars represent SE. Solid symbols: After the high temperature and photoperiod treatment, plants were dissected under a microscope to observe the presence of flower buds. Plants had not initiated flower primordia under these photoperiods. Open symbols: Inflorescence production continued throughout the test period under these photoperiods. The outlines of cultivation for each cultivar are shown in Table 1.

いる (Durner・Poling, 1985)。 また，“夏芳’は平均気温 $26^{\circ} \mathrm{C}$ 付近と，本実験より低い温度でも花芽分化が抑制されてい る（泰松・芳岡，1984）．温度の感受性に品種間差が存在す る可能性があるので，温度の範囲を広げて検討する必要が ある.

\section{摘 要}

低温に遭遇したイチゴの四季成り性品種 “夏芳”，“大石 四季成’，“夕よし’，“大和四季成”を供試して, $30 / 25^{\circ} \mathrm{C}$ の 高温条件下において日長処理を 16 週間行ったところ,いず れの品種も質的長日性を示し，“夏芳”は 14 時間以下，“大 石四季成’は 13 時間以下，“久ょし’は 12 時間以下，“大 和四季成’は 15 時間以下の日長で花芽分化が停止した。 た，低温に遭遇していない“夏芳”と“大石四季成”も， 低温に遭遇した株と同様に，それぞれ 14 時間以下，13 時 間以下の日長で花芽分化が停止し，質的長日性を示し，限 界日長は品種間で異なることが明らかとなった。

\section{引用文献}

Durner, E. F., J. A. Barden, D. G. Himelrick and E. B. Poling. 1984. Photoperiod and temperature effects on flower and runner development in day-neutral, Junebearing, and everbearing strawberries. J. Amer. Soc. Hort. Sci. 109: 396-400.

Durner, E. F. and E. B. Poling. 1985. Comparison of three methods for determining the floral or vegetative status of strawberry plants. J. Amer. Soc. Hort. Sci. 110: 808-811.

川村泰史・川下輝一・河野充憲. 1990. 四季成り性イチゴ の秋冬どり栽培に関する研究. 第 1 報. 鉢受け時期と育 苗環境. 徳島農試研報. 27: 29-38.

川下輝一. 1988. 四季成り性イチゴ新品種 ‘よし’ につ いて. 徳島農試研報. 25:1-4.

高野 浩・常松定信. 1993. 四季成り性イチゴの作型に関 する研究. 第4報. 一年生株に扣ける心止まり現象. 園 学雑. 62 (別1): 322-323. 
高野 浩・常松定信. 1994. 四季成り性イチゴの作型に関 する研究. 第5 報. 電照抢よび摘蕾処理が一年生株の心 止まりに及洔す影響. 園学雑. 63 (別1)：342-343.

熊倉裕史・宍戸良洋. 1995. イチゴ四季成り性品種の花芽 分化に及活す温度と日長の影響. 園学雑. 64: 85-94.

Nishiyama, M. and K. Kanahama. 2002. Effects of temperature and photoperiod on flower bud initiation of day-neutral and everbearing strawberries. Acta Hort. 567: 253-255.

西山 学・大川 亘・金浜耕基. 1998. 休眠期に打㚈る四 季成り性イチゴの栄養生長と生殖生長を誘導する温度 と日長条件. 園学雑. 67: 228-235.

西山 学・大川 亘・金浜耕基. 1999. 四季成り性イチゴ ‘サマーベリー’の一年生苗に打ける花房発生に及济す 温度と日長の影響. 園学雑. 68: 192-194.

Nishiyama, M., W. Ohkawa, Y. Kanayama and K. Kanahama. 2006. Critical photoperiod for flower bud initiation in everbearing strawberry 'Summerberry' plants grown at high temperature. Tohoku J. Agric. Res. 56(3-4): 1-8.

Oda, Y. and T. Yanagi. 1990. Studies on propagation by using runner apex tissue culture in everbearing strawberry. Abstr. 23rd Inter. Hort. Congress 1: 143.

施山紀男・今田成雄. 1990. イチゴ品種の生態特性に関す
る研究. 第4報. 四季成り性品種の生育々開花の季節推 移に及洁す日長の影響. 園学雑. 59 (別1)：436-437. 施山紀男・三浦周行・今田成雄. 1989. イチゴ品種の生態 特性に関する研究. 第2 報. 四季成り型とday-neutral型 の生長・開花に対する日長・気温の影響の差異. 園学 雑. 58 (別1): 342-343.

Smeets, L. 1980. Effect of temperature and daylength on flower initiation and runner formation in two everbearing strawberry cultivars. Sci. Hort. 12: 19-26.

泰松恒男. 1993. イチゴ四季成性品種の生態特性の解明並 びにその生産性の確立に関する研究. 奈良農試特別研 報. $1-206$.

泰松恒男・芳岡昭夫. 1984. 四季成りイチゴの生理生態特 性の解明に関寸る研究. 第1 報. 夏どり品種 “夏芳” の 露地条件下の收穫パターンと花成反応. 園学要旨. 昭 59秋: 186-187.

高橋春實. 2000. ‘大石四季成”。本に打怕四季成り性 イチゴ育種の先覚者大石俊雄のプロフィールと育種へ の思い. 日本イチゴセミナー紀. 9: 86-91.

刀祢茂弘. 1992. 四季成り性イチゴ ‘サマーベリー’ の収量 に及ぼす長日処理の影響. 園学雑. 61 (別2)：440-441. 